\title{
Efficacy of Irradiated Glyphosate Against Brachiaria plantaginea L.
}

\author{
Andre R. Machi ${ }^{1}$, Luiz S. Ferrari ${ }^{1,2}$ \& Valter Arthur ${ }^{1,3}$ \\ ${ }^{1}$ Institute of Energy and Nuclear Research, University of São Paulo, São Paulo, Brazil \\ ${ }^{2}$ Plant Production Department, College of Agriculture "Luiz de Queiroz", University of São Paulo, Piracicaba, \\ Brazil \\ ${ }^{3}$ Center for Nuclear Energy in Agriculture, University of São Paulo, Piracicaba, Brazil \\ Correspondence: Andre R. Machi, Institute of Energy and Nuclear Research, University of São Paulo, Box \\ 05508-000, São Paulo, SP, Brazil. E-mail: armachi@cena.usp.br
}

Received: April 12, 2018

doi:10.5539/jas.v10n7p383
Accepted: May 15, $2018 \quad$ Online Published: June 15, 2018

URL: https://doi.org/10.5539/jas.v10n7p383

\begin{abstract}
Glyphosate irradiated with cobalt-60 type Gammacell 220 at different rates was sprayed on seedlings of Brachiaria plantaginea L., a common weed, grown in pots (one seedling with 3-4 leaves in each pot), at different concentrations equivalent to $1 \mathrm{~L} \mathrm{~h}^{-1}$ or $3 \mathrm{~L} \mathrm{~h}^{-1}$. Each sample containing $40 \mathrm{ml}$ of the product (glyphosate) taken to a source of Cobalt-60 type Gammacell 220, under a dose rate of $0.312 \mathrm{kGy} /$ hour in doses of: T0, control (water instead of glyphosate); T1, glyphosate at $1.0 \mathrm{~L} \mathrm{~h}^{-1} ; \mathrm{T} 2$, glyphosate at $3.0 \mathrm{~L} \mathrm{~h}^{-1}$; T3, glyphosate irradiated at $250 \mathrm{~Gy}$ at $1.0 \mathrm{~L} \mathrm{~h}^{-1} ; \mathrm{T} 4$, glyphosate irradiated at $500 \mathrm{~Gy}$ at $1.0 \mathrm{~L} \mathrm{~h}^{-1} ; \mathrm{T} 5$, glyphosate irradiated at $750 \mathrm{~Gy}$ at $1.0 \mathrm{~L}$ $\mathrm{h}^{-1}$; and T6, glyphosate irradiated at $1000 \mathrm{~Gy}$ at $1.0 \mathrm{~L} \mathrm{~h}^{-1}$. The effects were assessed in terms of the extent of injury, where scale of $0 \%$ (no visible injury) to $100 \%$ (plant dead), number of tillers, weed survival and dry biomass produced by the plants. The most effective treatment was glyphosate irradiated at $250 \mathrm{~Gy} \mathrm{~h}^{-1}$ and applied at $1.0 \mathrm{~L} \mathrm{~h}^{-1}$. It is important to know that gamma radiation in glyphosate herbicide can be used without antagonistic interactions without cause resistance.
\end{abstract}

Keywords: weed biology, herbicide irradiation, Brachiaria plantaginea L.

\section{Introduction}

The One of the major challenges facing modern agriculture is to lower the amount of chemical pesticides applied per unit of land without compromising their efficacy (Tsai et al., 2005; Nuyttens et al., 2006; Cunha et al., 2010). Brachiaria plantaginea L., also known as alexandergrass, is a very common weed in both annual and perennial crops in Brazil and particularly serious in annual crops such as soybean and maize against which the weed is particularly competitive (Brighenti \& Oliveira, 2011), leading to substantial reduction in their yield (Dias et al., 2010; Pereira et al., 2010).

Currently, the most widely used herbicide to control alexander grass is glyphosate because it offers several advantages: it is non-selective, and therefore effective against a wide range of plants except those that have been genetically modified to be resistant to glyphosate; it is systemic and leaves no residues in soil; it can control both annual and perennial weeds; and it can also be used instead of tillage in natural agriculture because it can make the residual plants from a previous crop dry up - features that make this herbicide particularly suitable for the control of many species of Brachiaria spp. (Rodrigues \& Almeida, 2011; Zonetti et al., 2011).

Because weeds such as $B$. plantaginea are highly competitive, their being resistant to herbicides is not uncommon (Embrapa, 2013). Cavers and Benoit (1989) reported that prolonged use of triazines in maize in Ontario, Canada, altered the species composition and made the weed species more resistant to triazines.

Irradiation of herbicides has been shown to be an alternative method to overcome the problem of weeds developing resistance to herbicides, because radiation leaves no residues and does not cause resistance after its application. The method is already used successfully in several countries and also for other applications such as effluent treatment, pesticide degradation, water and soil decontamination, and food preservation (Arthur, 1997; Hiluey, 2005; Cantinha, 2008; Pestana, 2010).

The first step after an herbicide is irradiated is the formation of excited species, which, in turn, decompose into reactive species. These reactive species form reactive molecules, which interact and may form other compounds 
through free radicals such as ions, aqueous electrons, hydrogen atoms, and other molecular and gaseous products that may modify the substances present in the herbicide and make the herbicide more effective or less effective - the result is known to vary with the dose of gamma radiation (Campos, 2004).

The herbicide efficacy can be measured by three types of responses: synergistic, antagonistic, and neutral. Synergism occurs when the observed effect is higher than the isolated effect of each herbicide, and antagonism occurs when the effects of the herbicide mixture are less than the herbicidal effect of each herbicide applied alone. If herbicide interactions are not significant in either a synergistic or antagonistic response, a neutral response occurs (Colby, 1967; Blouin et al., 2004; Fish et al., 2016).

It was against this background that the present study sought to evaluate the efficacy of the herbicide glyphosate irradiated at different rates and applied at different concentrations against the weed B. plantaginea.

\section{Method}

The experiment was carried out at the University of São Paulo, College of Agriculture in the Plant Production Department and in the Center for Nuclear Energy in Agriculture in São Paulo, Brazil. Seedlings of $B$. plantaginea were collected from that part of the experimental area of the college to which no herbicide had been applied. The seedlings were transplanted immediately after collection into pots, one seedling in each pot. The experiment consisted of six treatments, each replicated twenty times.

\subsection{Irradiation of Glyphosate}

Vials containing $40 \mathrm{~mL}$ of the pure product (glyphosate) and wrapped in aluminium foil were placed in a Gammacell 220 irradiator (Nordion, Ottawa, Canada) installed at the Center for Nuclear Energy in Agriculture and irradiated at $0.312 \mathrm{kGy} \mathrm{h}^{-1}$. Glyphosate was tried at two concentrations, $1.0 \mathrm{~L} \mathrm{~h}^{-1}$ and $3.0 \mathrm{~L} \mathrm{~h}^{-1}$, either without irradiation or with irradiation at different doses, as $250 \mathrm{~Gy}, 500 \mathrm{~Gy}, 750 \mathrm{~Gy}$, and $1000 \mathrm{~Gy}$ (gray is the standard unit of absorbed ionizing radiation dose). The treatments were thus as follows: T0, control (water instead of glyphosate); T1, glyphosate at $1.0 \mathrm{~L} \mathrm{~h}^{-1} ; \mathrm{T} 2$, glyphosate at $3.0 \mathrm{~L} \mathrm{~h}^{-1} ; \mathrm{T} 3$, glyphosate irradiated at $250 \mathrm{~Gy}$ at $1.0 \mathrm{~L}$ $\mathrm{h}^{-1}$; T4, glyphosate irradiated at $500 \mathrm{~Gy}$ at $1.0 \mathrm{~L} \mathrm{~h}^{-1}$; T5, glyphosate irradiated at $750 \mathrm{~Gy}$ at $1.0 \mathrm{~L} \mathrm{~h}^{-1}$; and $\mathrm{T} 6$, glyphosate irradiated at $1000 \mathrm{~Gy}$ at $1.0 \mathrm{~L} \mathrm{~h}^{-1}$.

\subsection{Application of Glyphosate}

The herbicide was applied $24 \mathrm{~h}$ after irradiation using a pneumatic sprayer (40 psi or $275.8 \mathrm{kPa})$ with a fan-type nozzle (Teejet 8002) at a flow rate of $200 \mathrm{~L} \mathrm{~h}^{-1}$ and held $0.50 \mathrm{~m}$ above the target surface (individual seedlings, each with 3-4 leaves). After spraying, the pots were kept under ambient conditions ( $30-35^{\circ} \mathrm{C}, 70-75 \%$ U.R.) in a greenhouse and not watered for $24 \mathrm{~h}$ to ensure adequate foliar absorption of the herbicide and irrigated daily thereafter with an automatic sprinkler.

\subsection{Statistical Analysis}

The efficacy of glyphosate was assessed on a scale of $0 \%$ (no visible injury) to $100 \%$ (plant dead) (SBPC, 1995). From the 8th day after the application, the number of tillers produced was also recorded, and dry biomass of each plant was recorded 20 days after transplanting. Fisher's protected least significant difference (LSD; $\mathrm{P}=0.05$ ) was used for comparing the treatment means. The analyses were conducted using Excel $2010 \AA$ from Microsoft Office and the Statistical Analysis System ${ }^{\circledR}$ (SAS), ver. 9.3 (SAS Institute 2016).

\section{Results and Discussion}

\subsection{Extent of Injury}

The effect of glyphosate was obvious 20 days after transplanting at both the concentrations whereas the control plants showed no injury at all (Table 1). 
Table 1. Efficacy of glyphosate against B. plantaginea as measured 20 days after herbicide application

\begin{tabular}{ll}
\hline Treatment: Glyphosate concentration $\left(\mathrm{L} \mathrm{h}^{-1}\right)$ & $\%$ Control (extent of injury) \\
\hline Irradiation dose $(\mathrm{Gy})$ & $\pm \mathrm{SE}$ \\
\hline T0, Control (water instead of glyphosate) & $0.0 \pm 0.0$ \\
T1, Glyphosate $1.0 \mathrm{~L} \mathrm{~h}^{-1 * *}$ & $92.3 \pm 1.2$ \\
T2, Glyphosate $3.0 \mathrm{~L} \mathrm{~h}^{-1}$ & $99.0 \pm 1.1$ \\
T3, Glyphosate $1.0 \mathrm{~L} \mathrm{~h}^{-1}+250 \mathrm{~Gy}^{* *}$ & $98.5 \pm 1.3$ \\
T4, Glyphosate $1.0 \mathrm{~L} \mathrm{~h}^{-1}+500 \mathrm{~Gy}$ & $75.0 \pm 1.4$ \\
T5, Glyphosate $1.0 \mathrm{~L} \mathrm{~h}^{-1}+750 \mathrm{~Gy}$ & $77.5 \pm 2.1$ \\
T6, Glyphosate $1.0 \mathrm{~L} \mathrm{~h}^{-1}+1000 \mathrm{~Gy}$ & $53.7 \pm 1.5$ \\
\end{tabular}

Note. *Means followed by the same letter indicate that the differences were not significant at $5 \%$ (Tukey's test); ** Statistically significant.

The treatment with glyphosate irradiated at $250 \mathrm{~Gy}$ and applied at $1.0 \mathrm{~L} \mathrm{~h}^{-1}$ showed a synergistic response compared to glyphosate at that concentration without irradiation: the extent of injury was 6.2 percentage points greater, $98.5 \%$ versus $92.3 \%$ (the difference was statistically significant). At the next two higher doses but at the same concentration, the injury was less than $78 \%$, and at $1000 \mathrm{~Gy}$, it was $53.7 \pm 1.5 \%$ - all the three higher doses thus showed antagonism instead of synergy.

Although the maximum effect (99.0 \pm 1.1$)$ was seen in glyphosate at $3.0 \mathrm{~L} \mathrm{~h}^{-1}$ without irradiation, the value was not significantly different from that with glyphosate irradiated at $250 \mathrm{~Gy}$ and applied at $1.0 \mathrm{~L} \mathrm{~h}^{-1}$. Similar results also were also observed in fleabane seedlings (Conyza sp.), which recorded 100\% mortality when glyphosate, without irradiation, was applied at 3.0 $\mathrm{L} \mathrm{h}^{-1}$ (Walker \& Robinson 2008).

Growers can thus use glyphosate irradiated at $250 \mathrm{~Gy}$ at $1.0 \mathrm{~L} \mathrm{~h}^{-1}$ to control B. plantaginea and yet gain the same benefits as those from a higher dose $\left(3.0 \mathrm{~L} \mathrm{~h}^{-1}\right)$ while at the same time lowering the possibility of the weed developing resistance to the herbicide. Perhaps, a dose lower than 250 Gy can also be tested to obtain better used with similar results. This synergistic effect is probably due to the changes in chemical bonds in a variety of pesticides; these changes increase their penetrating power and ionizing properties but may prove either synergistic or antagonistic (Kung et al., 1953; Colby, 1967; Ionesou, 1968; Lippold, 1969; Horowitz \& Blumenfeld, 1973; Fish et al., 2015).

We did not come across any reports of the use of gamma radiation in herbicides for weed control; in some studies, glyphosate did not prove particularly effective when used by itself, but was more efficacious when used in combination with other herbicides. In Ponta Grossa in Parana, Brazil, glyphosate applied alone failed to control B. plantaginea but proved more effective when combined with flumioxazin (Constantin et al., 2005). Werth et al. (2010) observed that glyphosate by itself achieved 54\% control when used against Conyza bonariensis but the level increased to 85-93\% when combined with 2,4-D. Ramos and Durigan (1996) used the same mix to control Commelina virginica in citrus and found the mix more effective than glyphosate alone; however, Costa et al. (2011) found an antagonistic effect between the two herbicides. Fish et al. (2016) mixed imazamox with propanil and found the mix effective $(67 \%$ control) in controlling weeds in red rice because of the synergistic response.

\subsection{Dry Biomass}

The results were similar when the efficacy was assessed in terms of dry biomass of seedlings (Table 2). In the treatment with glyphosate irradiated at $250 \mathrm{~Gy}$ and applied at $1.0 \mathrm{~L} \mathrm{~h}^{-1}$, the dry mass of each plant was $1.31 \pm 1.4$ $\mathrm{g}$, compared to $1.73 \pm 1.5 \mathrm{~g}$ in glyphosate at the same concentration but without irradiation (the difference was significant). The lower biomass was probably because the plants lacked the resources to sustain the greater number of tillers they produced (4 tillers on average in the treatment with glyphosate irradiated at $250 \mathrm{~Gy}$ and applied at $1.0 \mathrm{~L} \mathrm{~h}^{-1}$ compared to 2.5 tillers (Table 2). 
Table 2. Dry biomass and number of tillers of $B$. plantaginea recorded after 20 days after application of glyphosate

\begin{tabular}{lll}
\hline Treatment: Glyphosate concentration $\left(\mathrm{L} \mathrm{h}^{-1}\right)$ & No. of & Dry biomass $(\mathrm{g})$ \\
\hline Irradiation dose $(\mathrm{Gy})$ & Tillers & $\pm \mathrm{SE}$ \\
\hline T0, Control (water instead of glyphosate) & 2.5 & $2.10 \pm 1.1$ \\
T1, Glyphosate $1.0 \mathrm{~L} \mathrm{~h}^{-1 * *}$ & 2.5 & $1.73 \pm 1.5$ \\
$\mathrm{~T} 2$, Glyphosate $3.0 \mathrm{~L} \mathrm{~h}^{-1}$ & 2.7 & $1.45 \pm 1.3$ \\
$\mathrm{~T} 3$, Glyphosate $1.0 \mathrm{~L} \mathrm{~h}^{-1}+250 \mathrm{~Gy}^{* *}$ & 4.0 & $1.31 \pm 1.4$ \\
T4, Glyphosate $1.0 \mathrm{~L} \mathrm{~h}^{-1}+500 \mathrm{~Gy}$ & 5.0 & $1.71 \pm 1.3$ \\
T5, Glyphosate $1.0 \mathrm{~L} \mathrm{~h}^{-1}+750 \mathrm{~Gy}$ & 4.5 & $1.71 \pm 1.3$ \\
T6, Glyphosate $1.0 \mathrm{~L} \mathrm{~h}^{-1}+1000 \mathrm{~Gy}$ & 4.7 & $1.62 \pm 1.2$ \\
& & $P<0.001$ \\
\hline
\end{tabular}

Note. * Means followed by the same letter indicate that the differences were not significant at $5 \%$ (Tukey's test); ** Statistically significant.

Although dry biomass was slightly greater $(1.45 \pm 1.3 \mathrm{~g})$ in the treatment with glyphosate at $3.0 \mathrm{~L} \mathrm{~h}^{-1}$ compared to that in glyphosate irradiated at $250 \mathrm{~Gy}$ and applied at $1.0 \mathrm{~L} \mathrm{~h}^{-1}(1.31 \pm 1.4 \mathrm{~g})$, the difference was not significant whereas at the three higher doses, the dry mass was significantly greater, at $1.60 \mathrm{~g}$ on average. The higher doses thus showed a neutral to each other and antagonist response in terms of the extent of injury (the injury was less) and in terms of dry biomass (which was greater), probably because irradiation at higher doses affected the herbicide adversely. The results in terms of the number of tillers were similar to those in terms of dry biomass, as explained earlier. The effect is probably a biological response of the plant to the irradiated herbicide. In general, the greater dry biomass in some treatments with or without gamma radiation-but mainly in the former category - reflects decreased control of $B$. plantaginea, the decrease being directly proportional to the dose.

The synergistic response may be due to the gamma radiation, the most important reactive species being solvated electrons and the hydroxyl radical. A solvated electron, for example, is especially important in radiation-induced dechlorination of organochlorinated substances, which include such pesticides as DDT, lindane, aldrin, endrin, heptachlor, dieldrin, chlordane, and mirex. The solvated electron reacts by dissociative attachment with these substances to generate an organic radical and a chloride anion. The organic radical scavenges a hydrogen atom from the solvent and a dechlorinated molecule is thus obtained (Lepine, 1991).

The irradiated herbice efficacy also was evaluated across of Figure 1, after 20 days the glyphosate response in treatments with radiation decrease proporcionally to the increase of doses, the from of 500, 750 and $1000 \mathrm{~Gy}$, the survival weeds was $20-50 \%$ at more when compared to others doses this study, suggested a antagonistic response.

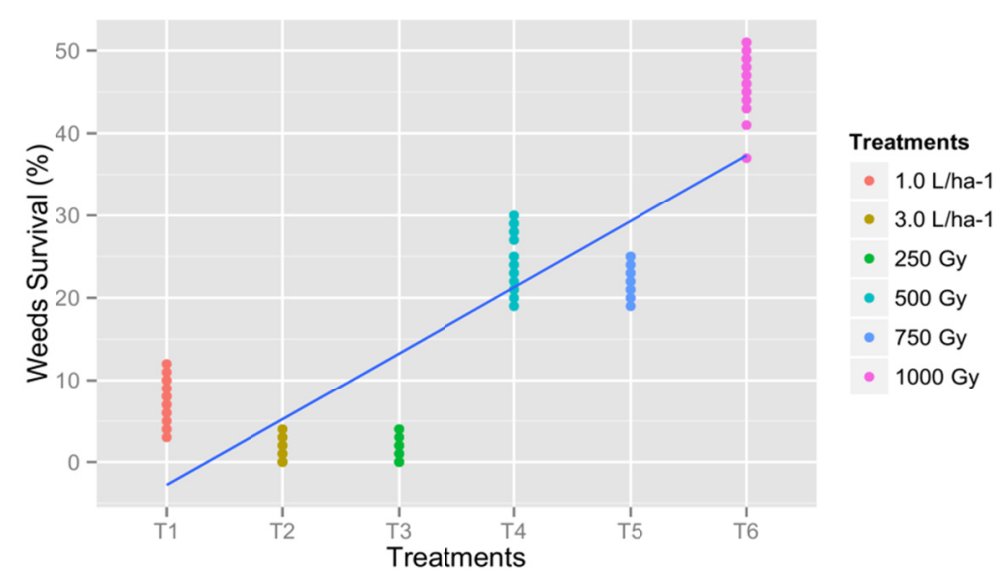

Figure 1. Glyphosate herbicide efficacy in B. plantaginea survival

Note. $* \mathrm{~T} 0$ (control): Inexistent data; ** Model Regression Linear: $\mathrm{y}=7.60 \pm 6.60 \mathrm{x}, \mathrm{R}^{2}=0.98$. 
In the without radiation doses, the glyphosate at $1.0 \mathrm{~L} \mathrm{~h}^{-1}$ not show good efficacy, about $7.7 \%$ of plants survival in comparison the 250 Gy with $1.5 \%$, a difference of $6.2 \%$ in efficacy, although the treatment with $3.0 \mathrm{~L} \mathrm{~h}^{-1}$ have showed $1 \%$ of weeds survival, not statistically differ. The great survival in different doses of radiation induced a antagonistic response in comparison to without irradiation doses, while that synergistic response was observed in glyphosate at $250 \mathrm{~Gy}$, and consequently increased the efficacy of the herbicide, reflected in the number of injury, tillers and the dry biomass.

However, an important factor that controls the efficacy of irradiated herbicide is its physical state. Organic substances contained in herbicides make that its compounds degradation be major than in the solid and crystalline compounds. Thus, if irradiated herbicide is applied on more hot temperatures, the herbicide degradation is likely to be higher, besides this the increase of doses applied also accelerate the degradation these organic compounds (Lepine, 1991; Arthur, 1997; Zona \& Sosa, 2003; Campos, 2004). Consequently, as our experiment was performed in ambient conditions above of $30 \mathrm{C}$, the low efficacy in higher doses of the study was accelerated, increasing the survival of weeds.

Although glyphosate at $3.0 \mathrm{~L} \mathrm{~h}^{-1}$ without radiation showed maximum control of the weed, the dose is three times that used in other studies and hence impracticable because it is both excessive and expensive. In addition, according to Christoffoleti (1997), higher doses of herbicides exercise greater selection pressure and thus favour the emergence of weed biotypes resistant to herbicides. Although the addition of multiple herbicide modes of action or mixtures can help prevent or delay the development of herbicide resistant weeds, the gamma radiations in herbicides not cause resistance. Glyphosate at $1.0 \mathrm{~L} \mathrm{~h}^{-1}$ is also the concentration recommended by the manufacturer but it has proved inferior to glyphosate at the same concentration and irradiated at $250 \mathrm{~Gy}$ in our results.

\section{Conclusion}

Thus, glyphosate irradiated at 250 Gy and applied at a concentration of $1.0 \mathrm{~L} \mathrm{~h}^{-1}$ is recommended for the control of $B$. plantaginea up to 20 days after transplanting as being not only effective but also viable economically in comparison glyphosate at 1.0 and $3.0 \mathrm{~L} \mathrm{~h}^{-1}$ without radiation. It is important to know that gamma radiation in herbicides can be used without antagonistic interactions in some doses, without cause resistance.

\section{References}

Arthur, V. (1997). Controle de insetos-praga por radiações ionizantes. Biológico, 59, 77-79.

Brighenti, A. M., \& Oliveira, M. F. (2011). Biologia de plantas daninhas. In J. R. Oliveira (Ed.), Biologia e manejo de plantas daninhas (pp. 1-36). Curitiba, Brasil: Omnipax.

Campos, S. X. de, Sanches, S. M., Falone, S. Z., \& Vieira, E. M. (2004). Influência da taxa de dose na degradação do herbicida ácido diclorofenóxiacético (2,4-d) por meio da radiação gama do cobalto-60. Ecletica Quimica, 29, 41-46. https://doi.org/10.1590/S0100-46702004000100005

Cantinha, R. S. (2008). Influência da radiação gama de alta taxa de dose na sobrevivência e reprodução de Biomphalaria glabrata (Unpublished doctoral dissertation, Universidade Federal de Pernambuco, Brazil).

Cavers, P. B., \& Benoit, D. L. (1989). Seed banks in arable land. In M. A. Leck, V. T. Parker, \& R. L. Simpson (Eds.), Ecology of soil seed banks (pp. 309-328). New York: Academic Press. https://doi.org/10.1016/ B978-0-12-440405-2.50019-1

Christoffoleti, P. J. (1997). Resistência de plantas daninhas aos herbicidas. Proceedings of Simpósio sobre herbicidas e plantas daninhas (pp. 75-94).

Colby, S. R. (1967). Calculating synergistic and antagonistic response of herbicide combinations. Weeds, 15, 20-22. https://doi.org/10.2307/4041058

Constantin, J., Oliveira, R. S. Jr. de, Martins, M. C., Lopes, P. V., \& Barroso, A. L. L. de. (2005). Dessecação em áreas com grande cobertura vegetal: alternativas de manejo. Informações Agronômicas, 111, 1-9.

Costa, N. V., Martins, D., Costa, A. C. P. R., \& Cardoso, L. A. (2011). Eficácia do Glyphosate e 2,4-d no controle de espécies de trapoerabas (Commelina spp.). Journal of Biosciences, 27, 718-728.

Cunha, J. P. A. R., Silva, L. L., Boller, W., \& Rodrigues, J. F. (2010). Aplicação aérea e terrestre de fungicida para o controle de doenças do milho. Revista de Ciências Agronômicas, 41, 366-372. https://doi.org/ $10.1590 / \mathrm{S} 1806-66902010000300007$ 
Dias, A. C. R., Carvalho, S. J. P., Brancalion, P. H. S., Novembre, A. D. L. C., \& Christoffoleti, P. J. (2010). Competitiveness of alexandergrass or bengal dayflower with soybean. Planta Daninha, 28, 515-522. https://doi.org/10.1590/S0100-83582010000300008

EMBRAPA (Empresa Brasileira de Pesquisa Agropecuária). (2017). Capim-Amargoso: Mais um caso de resistência ao Glifosato. Retrieved from http://www.cnpso.embrapa.br/download/Capim_amargoso.pdf

Fisch, J. C., Webster, E. P., Blouin, D. C., \& Bond, J. A. (2016). Imazamox plus propanil mixtures for grass weed management in imidazolinone-resistant rice. Weed Technology, 30, 29-35. https://doi.org/10.1614/WT-D15-00027.1

Fish, J. C., Webster, E. P., Blouin, D. C., \& Bond, J. A. (2015). Imazethapyr co-application interactions in imidazolinone-resistant rice. Weed Technology, 29, 689-696. https://doi.org/10.1614/WT-D-15-00030.1

Hiluey, L. J., Gomes, J. P., Almeida, F. de A. C., Silva, M. S., \& Alexandre, H. V. (2005). Avaliação do rendimento do fruto, cor da casca e polpa de manga tipo espada sob atmosfera modificada. Revista Brasileira de Produtos Agroindustriais, 7, 151-157. https://doi.org/10.15871/1517-8595/rbpa.v7n2p151-157

Horowitz, M., \& Blumenfeld, T. (1973). Effect of gamma radiation on the bioactivity of herbicides. Weed Science, 21, 281-284.

Ionesou, S. (1968). Synthesis and decomposition induced by ionizing radiation. In IAEA (Ed.), Radiation Chemistry and Its Application (pp. 97-124). International Atomic Energy Agency, Vienna.

Kung, H.-C., Gaden, E. L. Jr., \& King, C. G. (1953). Vitamins and enzymes in milk: Effect of gamma radiation on activity. Journal of Agricultural and Food Chemistry, 1, 142-144. https://doi.org/10.1021/jf60002a003

Lippold, P. C., Cleeve, J. S., Massey, L. M., Bourke, Jr. J. B., \& Avens, A. W. (1969). Degradation of insecticides by Co-60 gamma radiation. Journal of Economic Entomology, 62, 1509-1510. https://doi.org/10.1093/ jee/62.6.1509

Nuyttens, D., De Schampheleire, M., Steurbaut, W., Baetens, K., Verboven, P., Nicolai, B., ... Sonck, B. (2006). Experimental study of factors influencing the risk of drift from field sprayers: Part 1: Meteorological conditions. Aspects Applied Biology, 77, 01-08.

Pereira, M. R. R., Martins, D., Silva, J. I. C., Rodrigues-Costa, A. C. P., \& Klar, A. E. (2010). Efeito de herbicidas sobre plantas de Brachiaria plantaginea submetidas a estresse hídrico. Planta Daninha, 28, 1047-10580. https://doi.org/10.1590/S0100-83582010000500013

Pestana, R. K. N., Amorim, P. E. S., Oliveira, S. de, \& Tulmann, N. A. (2010). Irradiação gama para mutagênese in vitro em bananeira 'Terra Maranhão'. Pesquisa Agropecuária Brasileira, 45, 1328-1330. https://doi.org/10.1590/S0100-204X2010001100015

Ramos, H. H., \& Durigan, J. C. (1996). Avaliação da eficiência da mistura pronta de Glyphosate + 2,4-D no controle da Commelina virginica L. em citros. Planta Daninha, 14, 33-41. https://doi.org/10.1590/ S0100-83581996000100004

Rodrigues, B. N., \& Almeida, F. L. S. (2011). Guia de herbicidas (p. 697). Londrina, Paraná: Authors Edition.

SAS Institute. (2016). The SAS System for Windows (Release 9.3). SAS Institute, Cary, N.C.

Tsai, M., Elgethun, K., Ramaprasad, J., Yost, M. G., Felsot, A. S., Hebert, V. R., \& Fenske, R. A. (2005). The Washington aerial spray drift study: Modeling pesticide spray drift deposition from an aerial application. Atmospheric Environment, 39, 6194-6203. https://doi.org/10.1016/j.atmosenv.2005.07.011

Walker, S. R., \& Robinson, G. R. (2008). Flaxleaf fleabane-The next glyphosate resistant weed? $16^{\text {th }}$ Australian Weeds Conference. Retrived from http://caws.nzpps.org/awc/2008/awc200810881.pdf

Werth, J., Walker, S., Boucher, L., \& Robinson, G. (2010). Applying the double knock technique to control Conyza bonariensis. Weed Biology Management, 10, 1-8. https://doi.org/10.1111/j.1445-6664.2010.00360.x

Zona, R., \& Solar, S. (2003). Oxidation of 2,4-dichlorophenoxyacetic acid by ionizing radiation: Degradation, detoxification and mineralization. Radiation Physics and Chemistry, 66(2), 137-143. https://doi.org/ 10.1016/S0969-806X(02)00330-4

Zonetti, P. C., Oliveira, D., Sayuri, L. S., Bonini, E. A. F., Lourdes, L. M. de, \& Osvaldo, F. F. (2011). Growth and root lignification of susceptible and glyphosate-resistant soybean. Acta Scientiarum Agronomy, 33, 291-295. https://doi.org/10.4025/actasciagron.v33i2.6305 


\section{Copyrights}

Copyright for this article is retained by the author(s), with first publication rights granted to the journal.

This is an open-access article distributed under the terms and conditions of the Creative Commons Attribution license (http://creativecommons.org/licenses/by/4.0/). 